\title{
Colorectal Mucosa-Associated Lymphoid Tissue Lymphoma
}

National Cancer Institute

\section{Source}

National Cancer Institute. Colorectal Mucosa-Associated Lymphoid Tissue Lymphoma. NCl Thesaurus. Code C96506.

An extranodal marginal zone lymphoma of mucosa-associated lymphoid tissue that arises from the colon or rectum. 